\title{
GOETHE COMO CRÍTICO
}

\section{ERnSt Robert CuRtius}

crítica literária não tem um lugar reconhecido na vida intelectual alemã. A Alemanha não teve um Sainte-Beuve, e provavelmente também não pode tê-lo. Cultura literária é, entre nós, assunto de algumas individualidades dispersas, não uma necessidade do público leitor. Falta uma existência assegurada de tradição literária. O que se produz como Poesia [Dichtung] vem a ser consumido como visão de mundo [Weltanschauung]. Os grandes jornais alemães empregavam críticos fixos de teatro e música (sabidamente música, teatro e filme formam a "cultura" ou a "vida cultural" e podem ser "exercidos" profissionalmente). Mas eles não possuíam nenhum crítico literário. Conforme os livros chegavam, eram distribuídos de forma aleatória aos colaboradores. Suas vozes não possuíam qualquer peso, não podiam ter. Também não era melhor nos jornais maiores. O curto florescimento do Caderno Mensal do Sul da Alemanha [Süddeutschen Monatshefte] com Josef Hofmiller como crítico foi uma exceção que confirma a regra. A França possuía um Albert Thibaudet; a Inglaterra, um órgão de resenhas como o Times Literary Supplement. Não tínhamos nada do mesmo nível para contrapor.

Nem sempre foi assim. Trata-se de um fenômeno de decadência merecedor de uma análise mais atenta. Tácito e Quintiliano investigaram a decadência da arte da eloquência [Beredsamkeit] romana. Em 1812, Adam Müller proferiu em Viena "Doze discursos sobre a eloquência e sua decadência na Alemanha". Poder-se-ia escrever um capítulo sobre a crítica e sua decadência na Alemanha, pois entre 1750 e 1812 houve uma crítica alemã. Esse espaço de tempo corresponde ao período de vida de Goethe. Mas ao mesmo tempo, esta é a era das revoluções, a partir das quais o mundo moderno surgiu. Na Inglaterra acontecia a Revolução Industrial; na França, a cultural; na Alemanha, a filosófica e científica, marcada pelos nomes de Lessing e Herder, Winckelmann e Friedrich Schlegel, Kant, Fichte e Hegel. Dessas três revoluções, a mais fácil de ser reconhecida foi a francesa. Compreensivelmente, a alemã foi registrada primeiramente apenas na Alemanha e, mais precisamente, pelo romantismo. Friedrich Schlegel e Adam Müller a conceberam como correspondente à Revolução Francesa. Muito mais tarde, a Revolução Industrial da Inglaterra foi reconhecida e assim chamada como acontecimento histórico de primeira grandeza.

Quando o romantismo alemão falava de uma revolução filosófica e científica, ele se valia de uma metáfora política. Mas com isso foi marcado um acontecimento 
real e significativo: um movimento que abrangia todos os âmbitos da vida espiritual. Foi dividido em três gerações que se interpenetravam. Atuavam juntos filósofos e estudiosos da Antiguidade, poetas e historiadores; sem intenção, mas de modo tal como se alguém lhes houvesse incumbido de realizar uma obra em conjunto. Porém o elemento mediador, o fluido que permeava a todos, era o espírito da crítica, essa palavra tomada no sentido mais amplo que abrange a Crítica da razão de Kant, assim como o Laocoonte de Lessing; a história da arte de Winckelmann assim como as preleções de história da literatura dos Schlegel; os Discursos sobre a religião de Schleiermacher, assim como as Preleções sobre a ciência e literatura alemãs de Adam Müller (1805).

A essência de todo o movimento era: tornar presente e compreender toda a tradição europeia. Tal entendimento era, porém, ao mesmo tempo uma nova valoração e uma tomada de consciência. Isso significava, caso possa utilizar essa expressão, uma integração. E ela foi possível apenas a partir de um novo nível de consciência: superação do Iluminismo [Aufklärung] por meio de uma filosofia crítica. Esta passou no mesmo século por todos os níveis de desenvolvimento dialético - indo da Crítica da razão pura de Kant até a morte de Hegel - um processo que só possui analogia com o pensamento dos pré-socráticos. A filosofia alemã se divide em escolas dissidentes. Mas para a crítica, isso significava um ganho. Ela tinha a possibilidade de se livrar de todo ponto de vista escolar, para compreender o filosofar em si como função pura e como potenciação do espírito. Isso é o que significa a frase de Novalis, a qual Walter Pater ${ }^{1}$ adora citar: "Filosofar significa vivificar". É o que pensa também Friedrich Schlegel quando ele define a crítica como "entendimento do entender" [Verstehen des Verstehns].

A teologia de Aristóteles concebia o divino espírito cósmico [Weltgeist] como o "pensar sobre o pensar". O idealismo alemão fez uso dessa função para a filosofia. A fórmula de Friedrich Schlegel a transferiu para a crítica. Poder-se-ia expressar também da seguinte forma o conteúdo do pensamento: crítica é a literatura da literatura. Ou de forma mais explícita: crítica é a forma da literatura, cujo objeto é a literatura. T. S. Eliot disse uma vez que o romance é a forma na qual a literatura "afeta um maior número". Crítica, então, acrescentamos, é a forma na qual ela afeta em menor número. Poesia hermética encontra glosadores [hermeneutas] e adeptos. A crítica parece estar predestinada aos happy few; na Alemanha pelo menos.

\section{2}

Na grande época da crítica alemã, Goethe se situa como receptor e participante, como colaborador e como antagonista. Acolheu a obra de Lessing, Herder e Winckelmann. Em 12 de fevereiro de 1781, escreve à Sra. von Stein: "Um quarto de hora antes de chegar a notícia da morte de Lessing, tinha planos de visitá-lo. Com ele perdemos muito, muito. Mais do que pensamos". A relação com Herder, apesar de toda conturbação, foi altamente produtiva e descrita em Poesia e verdade.

${ }^{1}$ Walter Horatio Pater (1839-1894), ensaísta e crítico literário inglês. (N.T.) 
Ao "maravilhoso" Winckelmann, Goethe dedicou uma de suas obras mais belas e desconhecidas, uma biografia com uma perspectiva histórico-universal. Nela também encontra ensejo para dizer umas palavras sobre a filosofia e sua posição no movimento alemão. Desde sempre os filósofos haviam atraído para si o ódio dos "homens do mundo e da vida" [Welt- und Lebensmenschen]. Já que a filosofia, segundo sua natureza, reclama para si aquilo que há de mais universal e elevado, "dessa forma, ela tem de apreender as coisas do mundo como contidas nela, observar e tratá-las como subordinadas a ela". Goethe considera isso como uma "presunçosa pretensão"; assim como Winckelmann reclamara amargamente da filosofia de seu tempo e sua ampla influência.

\footnotetext{
Contudo, no momento em que temos em vista os acontecimentos dos últimos tempos, talvez seja aqui o lugar certo para fazer uma observação, a qual podemos manter pelo resto de nossas vidas: a de que, em relação àquele grande movimento filosófico iniciado por Kant, nenhum homem de ciência impunemente o rejeitou, a ele se contrapôs ou o menosprezou, com exceção dos verdadeiros estudiosos da Antiguidade, os quais, devido a especificidade de seus estudos, parecem ter sido colocados em posição privilegiada em relação a todos os outros homens.
}

Faz-se reverência à filosofia, mas o estudioso da Antiguidade está, de todos os modos, dispensado de fazê-la. De certa maneira, ele é assim duplamente favorecido. Goethe livra a pesquisa histórica das pretensões totalitárias da filosofia. Está definido o ponto de vista que Ranke e Burckhardt logo adotarão. Esse distanciamento em relação à filosofia já remete ao século XIX, o século da história. Ao mesmo tempo significa um marco fronteiriço que Goethe interpõe entre si e os jovens críticos. Não cabe aqui descrever como se institui esse marco divisor. Com os vizinhos do lado (os irmãos Schlegel e Adam Müller) pode haver pontos de contato ou desavenças. Porém eles estão excluídos do "país da arte" goethiano.

Nós definimos crítica como o tipo de literatura cujo objeto é a literatura. Essa definição abrangente do conceito é especialmente recomendada diante de uma obra crítica tão universal como foi a de Goethe. O ajuizamento de novas produções é apenas uma província do reino da crítica. Em minha opinião, existe apenas uma única descrição completa desse reino: Die History of Criticism de Georg Saintsbury, que data de apenas meio século. O autor declara o valor de Goethe enquanto crítico como uma "superstição já superada". Em 1858, contudo, Sainte-Beuve homenageou Goethe como o "maior de todos os críticos". Eu entendo a contradição, pelo fato de Saintsbury conhecer pouco Goethe e, por isso, não pode tê-lo visto corretamente. De fato, a crítica de Goethe só pode ser apreciada quando é compreendida em conexão com o universo de seus pensamentos como um todo. Suas recensões do livro de Grübel, Poesias no dialeto de Nuremberg (Gedichten in Nürnberger Mundart), ou de Olfried e Lisena de Hagen, por exemplo, podem parecer estranhas, mas elas têm de ser consideradas dentro da economia do sistema de Goethe de ordenação e formação do gosto. Mas não é em seus Escritos sobre Literatura que se acha o Goethe crítico. Suas reflexões sobre literatura e a função social do poeta são encontradas de forma dispersa no Wilhelm Meister, no Tasso, nas Notas sobre o Divã e nas Máximas. As conversações com Eckermann oferecem um 
rico material; na verdade, as conversas são muitas vezes condicionadas por alternados estados de ânimo, já que Goethe era tão sensivelmente dependente da posição do sol e do barômetro. Elas fornecem material limitado também pela personalidade subalterna do ouvinte, mas ao qual se pode atribuir autoridade, na medida em que Goethe examinou os manuscritos. Mas a isso ainda se deve acrescentar, a fim de se constituir o corpus da crítica goethiana, passagens de seus dramas de juventude, nas quais zomba da maneira aristofânica e lucianesca ${ }^{2}$ das manias literárias em voga; também muita coisa de suas poesias; das notas ao Sobrinho de Rameau; ${ }^{3}$ da inesgotável riqueza de suas cartas. Os Escritos sobre ciência da natureza também possuem filões de ouro em termos de crítica. Nos Materiais para a história da doutrina das cores é discutido o conceito de tradição, o que deu ensejo para delinear uma caracterização comparativa da Bíblia, de Platão e de Aristóteles.

\section{3}

Sigamos adiante. Somente sob a luz de sua doutrina da natureza, a teoria da literatura de Goethe torna-se transparente. Como se sabe, para Goethe, assim como para a história da criação da Bíblia, a oposição original entre luz e treva é um fenômeno primordial. Em Goethe essa oposição também é definida como criação divina: "A luz é uma das forças e virtudes originais criadas por Deus, a qual se empenha em representar uma analogia [Gleichnis] do divino na matéria". O material é ou transparente, ou opaco ou turvo. "Então, quando a virtude da luz se empenha por atravessar o meio turvo, embora de modo tal que sua força original é retida, mas que, todavia, sempre continua a atuar, então se torna visível sua analogia (Gleichnis) como amarelo ou amarelo-avermelhado." Este é um teorema da doutrina das cores. Transposta na linguagem poética:

Als die Welt im tiefsten Grunde

Lag an Gottes ewger Brust,

Ordnet' er die erste Stunde

Mit erhabner Schöpfungslust.

Und er sprach das Wort: "Es werde!"

Da erklang ein schmerzlich Ach!

Als das All mit Machtgebärde

In die Wirklichkeiten brach!

Auf tat sich das Licht; so trennte

Scheu sich Finsternis von ihm,

Und sogleich die Elemente

Scheidend auseinander fliehn.

Rasch in wilden, wüsten Träumen

Jedes nach der Weite rang,

Starr, in ungemeßsnen Räumen,

Ohne Sehnsucht, ohne Klang.

${ }^{2} \mathrm{O}$ autor se refere aos escritores gregos Aristófanes e Luciano de Samósata (século II d.C.). (N.T.)

${ }^{3}$ Tradução de Goethe da peça de Diderot. (N.T.) 


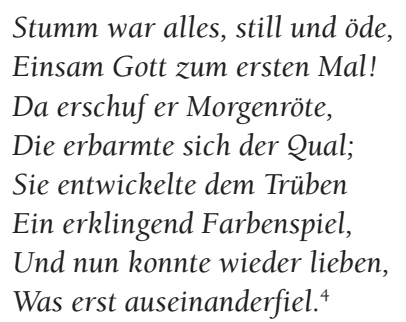

A aurora corresponde ao amarelo ou ao amarelo-avermelhado. "porém, caso um material escuro faça limite ao turvo, de modo que a virtude [Tugend] da luz não consiga prosseguir, mas que do turvo iluminado retorne como um reflexo, então o análogo disso é azul e azul-avermelhado". A luz: análogo de Deus; as cores: análogas à da luz; ao formular o axioma fundamental da Doutrina das cores, Goethe já pensa por meio de analogias. Sereno e turvo, sombrio e obscuro logo se tornam analogias próprias para situações relativas à história e à alma humana. "Os obscurecimentos e iluminações do homem fazem seu destino" (a Eckermann, 1828). Aplicação à história e à literatura:

Podemos aproveitar tão pouco dos obscuros tempos da antiguidade alemã como das canções sérvias e de poesias bárbaras de povos semelhantes. Ao lê-las, interessamo-nos por elas durante algum tempo, mas somente até concluir a leitura para logo em seguida as deixamos de lado. O homem já é obscurecido por meio de suas paixões e pelo destino, por isso não necessita ainda mais obscuridade, com as trevas de uma época bárbara. O que necessita é claridade, serenidade, voltar-se para aquelas épocas da arte e da literatura em que homens extraordinários alcançaram a mais perfeita formação, tanto que a eles próprios faziam bem e ainda estavam na posição de derramar sobre outros a bem-aventurança de sua cultura. ${ }^{5}$

Do mesmo modo que iluminação e obscurecimento, assim se correspondem barbárie e formação. Entre os polos desses pares opostos acontece uma permuta necessária, um movimento pendular. Épocas de obscurecimento devem, portanto, retornar periodicamente. Caso isso seja entendido como processo regular, então se está em um patamar, a partir do qual uma nova barbarização - como nós hoje a vivenciamos - a qual na verdade não se precisa aceitar, mas que da qual também não se poderá reclamar. "O círculo que a humanidade tem de percorrer é suficientemente determinado e, a despeito da longa paralisação feita pela barbárie, ela já

${ }^{4}$ Divã Oriental-ocidental (Livro de Suleika), "Wiederfinden" - Reencontro. [Quando o mundo em seu mais profundo fundamento / Repousava no eterno peito de Deus, / Ele ordenou a primeira hora / Com sublime prazer de criação, / Ele proferiu a palavra; "Faça-se!" / Então ressoou um doloroso ai! / Quando o universo com gesto poderoso / Rompeu em realidades.// A seguir fez-se a luz: dela / timidamente a escuridão se afastou, / E tão logo os elementos / Correram a se separar. / Rápidos, em desérticos sonhos selvagens / Cada um lutava pela amplidão / Obstinadamente, em espaços imensuráveis, / Sem nostalgia, sem som. // Emudecido tudo estava, calmo e ermo, / Deus sozinho, pela primeira vez! / Então ele criou a Aurora, / Que se apiedou do sofrimento; / Ela desenvolveu da turbi$\mathrm{dez} /$ Um soante jogo de cores / E assim pode amar novamente / O que antes havia se separado.] (N.T.)

${ }^{5}$ Conversações com Eckermann, 3 out. 1828. (N.T.) 
o percorreu mais de uma vez. Caso se queira atribuir a ela um movimento espiral, assim ela retorna sempre de novo àquela região, a qual já percorrera uma vez".

Predomínio da luz sobre a turbidez é o estado que está em conformidade com o pensamento de Goethe. Ele designa esse estado com a palavra "sereno" [heiter]. Na decadente consciência da língua do presente ela é sinônima de "alegre" [froh]. Originalmente ela foi usada na descrição de um céu diurno ou noturno sem nuvens, como a palavra em latim "serenus". No manuscrito do quarto ato de Ifigênia em Táuris, terminado em Schwalbestein, nas cercanias de Ilmenau, anota Goethe: sereno die, quieta mente. Em 1775 elege a "maravilhosa estrela da manhã" como brasão. Em Dornburg - verão de 1828 - ele frequentemente ficava à janela antes do irromper do dia para "gozar do espetáculo dos três planetas que agora estavam em conjunção e refrescar-se junto ao crescente esplendor da aurora". O êxodo de Israel pelo deserto é visto na imagem de uma turvação:

O sereno céu noturno, incandescente por incontáveis estrelas, para o qual Abraão foi indicado por seu Deus, não estende mais sua cabana de ouro sobre nós... Todos os fenômenos alegres se foram, apenas chamas de fogo aparecem em todos os cantos e becos. O Senhor, que havia chamado Moisés por meio da sarça ardente, marcha diante da multidão em uma fumaça ardente, a qual se toma de dia por uma coluna de nuvens e de noite por meteoro de fogo.

$\mathrm{Na}$ imagem da noturna claridade estrelar, Goethe avista a mais almejada analogia da relação com o universo:
Hast du so dich abgefunden, Werde Nacht und Äther klar, Und der ew'gen Sterne Schar Deute dir belebte Stunden, Wo du hier mit Ungetrübten, Treulich wirkend, gern verweilst Und auch treulich den geliebten Ewigen entgegeneilst. ${ }^{6}$

Em 1826, quando escreveu uma crítica sobre uma obra histórica de Schlosser, Goethe observou: "O autor pertence àqueles que a partir da escuridão almejam a clareza, um gênero ao qual também pertencemos". "Escuro", "sombrio", "turvo" são exemplos da linguagem do crítico Goethe, formas de rejeição. Por outro lado, o maior elogio pode ser exemplificado quando ele fala sobre o romance pastoral de Longo:.7 "Estamos em meio ao dia mais claro... nenhum vestígio de dias tur-

6 "Trauerloge", 1816 Poema feito por Goethe em memória a diversos amigos falecidos e proferido em uma sessão da loja maçônica [Trauerloge, 1816]. [Quando te conformares / Resplandecerão noite e firmamento / E o conjunto das estrelas eternas / Te anunciarão horas vívidas / Assim como aqui, onde, livre de turvações / Atuando lealmente, contente ficaste por algum tempo / E também lealmente corrias ao encontro / Dos amados seres eternos.] (N.T.)

${ }^{7}$ Longo (gr. $\Lambda$ ó $\gamma$ os, lat. Longus), escritor grego do século II ou III d.C., autor do romance pastoril Dáfnis e Cloé, também chamado de As pastorais. (N.T.) 
vos, de névoa, de nuvens e umidade, temos sim o céu mais azulado e puro". Esta obra lhe é preferível ao "bom Virgílio". Uma infração contra o credo ortodoxo do classicismo.

4

A crítica [Urteil] em relação a Longo poderia ser um sinal de aviso para todos aqueles que gostariam de conservar Goethe na Grécia clássica. No Goethe da Itália, faz-se presente uma tendência clássica, mesmo que não atue sozinha (no jardim da Vila Borghese foi escrita a "cena da bruxa" do Fausto I); e depois na época da amizade com Schiller. Entretanto, o Goethe tardio estabelece uma nova relação com a Antiguidade. A Antiguidade tardia torna-se seu lugar de escolha. Ele era da opinião de que já tinha vivido uma vez no círculo do imperador Adriano (1815, em conversa com Boisserée) ${ }^{8}$ A noite "clássica" de Valpurgis é uma abreviatura de toda a Antiguidade, na qual os campos de batalha de Pidna ${ }^{9}$ e Farsalos $^{10}$ são tão fortemente acentuados quanto o período arcaico dos heróis. Seu ornamento mitológico-filosófico foi preponderantemente tomado de autores da Antiguidade tardia; mas também o caminho de Fausto até as Mães se relaciona com apontamentos de Plutarco. Não apenas um recorte "clássico" - não, a Antiguidade é mencionada em todas suas fases e metamorfoses; sem paideia ou furor paedagogicus. Uma Antiguidade espiritual, reproduzida de maneira sugestiva e abstrata, como nas obras tardias de grandes mestres. "O tratamento devia, cada vez mais, passar do específico ao genérico", disse Goethe a Riemer que prossegue o relato: "Já em idade avançada, Ticiano, o grande colorista, pintou aquela cena que ele já havia imitado antes tão concretamente, mas desta vez apenas in abstracto, como, por exemplo, o veludo, apenas como ideia daquilo. Uma anedota que Goethe me contou repetidas vezes em referência a si mesmo".

Herman Hefele elogiou "o vigor e magnificência barrocos" dos versos da "Noite clássica de Valpúrgis". A cena do mar, o hino ao que se põe em movimento, é "uma esplendorosa fonte romana de Bernini só que fundida em palavras" - "da mesma forma que o barroco é a forma na qual o espírito alemão pode plasticizar o clássico de modo mais retumbante. A inteligente formulação marca, caso se desembarace o pregueado histórico-artístico, nada além do fato de que Fausto II não faz parte da cataforia do clássico. A essência do mundo clássico é vista pela perspectiva de um

${ }^{8}$ Goethe fez alusão a versos de Adriano em 1770, e depois na Elegias Romanas (Livro I, Nr. XV). Nos Anos de Peregrinação foi mencionado como "bendito aquele nobre imperador peregrino Adriano". [Goethe refere-se aqui ao imperador Públio Élio Trajano Adriano (76-138), mais conhecido apenas como Adriano. Foi imperador romano de 117 a 138. (N.T.)]

${ }^{9}$ Curtius refere-se aqui à Batalha de Pidna, cidade no noroeste da Grécia, ocorrida em 168 a.C. entre o exército romano e o macedônico, Terceira Guerra Macedônica, e que marcou o início da supremacia de Roma na região da Macedônia, pondo fim ao Império constituído por Alexandre, o Grande. (N.T.)

${ }^{10}$ Batalha de Farsalos, ocorrida em 9 de agosto de 48 a.C. entre Caio Júlio César e Cneu Pompeu Magno, marco do fim da República e ascensão de César, constituindo a partir daí o Império Romano. (N.T.) 
tempo antigo que não está ligado a nenhuma época histórica. A Roma da guerra civil está refletida no poema épico do tempo de Nero. A Hélade da época heroica aparece junto ao tempo das Cruzadas, e vemos o Peloponeso ocupado por germanos. Filemon e Báucis são transplantados das esferas helenístico-ovidianas até o Mar do Norte. Tempos e lugares sobrepõem-se uns aos outros, transpostos para a atemporalidade alegórico-simbólica que conhecemos dos palcos de mistério da Idade Média, de Calderón e de Hofmannstahl. Essa forma artística, tão distante da grega, poderia ser concebida como uma conservação da maneira medieval ou renascentista - caso não fosse a cesura de um classicismo (Ifigênia, Tasso), formado a partir de Racine, e que a separaria disso. Não ocorre uma continuidade, mas sim o retorno a um patamar mais elevado - "tendência espiral", tomando emprestado um conceito da ciência da natureza de Goethe.

Tal transferência está de acordo com a forma de pensar de Goethe. A oposição primordial entre o sereno e o turvo alcança, conforme vimos, as esferas da natureza e do espírito. Através das cores complementares Goethe via "uma grande lei que perpassa toda a natureza", a lei da "alternância necessária". "Talvez", acrescenta ele, "as divertidas cenas intercaladas nas tragédias de Shakespeare se baseiem nesta lei... ela parece não ser aplicável somente às mais elevadas tragédias gregas". Aqui temos o caso de obras que, tomadas como clássicos exemplares, parecem contradizer uma lei tida como universal. Do mesmo modo, uma relativização de normas clássicas pode resultar da observação da natureza. É bem característico como Goethe pensa em tal situação. Ele constata que tudo estaria interligado; uma lei da teoria das cores poderia servir a uma análise das tragédias gregas. "É preciso apenas se resguardar de ir longe demais com uma lei tal, e tomá-la como base para fenômenos heterogêneos; se estará mais seguro, caso seja usada apenas como um analogon, como um exemplo". Ou seja, a transposição de conceitos da ciência natural para a esfera dos conceitos da vida intelectual possui para Goethe apenas o caráter de uma referência analógica [analogisch]. Isso vale também, no sentido mais estreito, para os conceitos de metamorfose e formação orgânica. "A planta segue de botão em botão e termina com o florescimento e a semente". Goethe encontra analogias [Analogien] para isso na formação da lagarta, dos animais vertebrados e, finalmente, em "grandes corporações" como a da colônia de abelhas. "Desta forma, um povo produz seus heróis que, como os semideuses, estão no poder para proteção e salvação; e do mesmo modo se unificaram as forças poéticas dos franceses em Voltaire." Grandes povos, como os franceses, aparecem aos pesquisadores da natureza como "corporações", como a sociedade das abelhas. Esta produz a rainha e a coloca como chefe. Dessa maneira Voltaire é a França elevada à potência. Trata-se aqui de uma consideração espirituosa, divertida e sem compromisso. Falharia aquele que quisesse reduzir a morfologia de Goethe ao esquema da formação dos botões e das vértebras. É bastante instrutivo que o fenômeno Voltaire ache outro desaguadouro que esteja livre de botânica e osteologia:

Quando famílias conservam-se por muito tempo, pode-se então notar que a natureza finalmente produz um indivíduo que congrega em si as peculiaridades de todos seus antepassados e reúne todas as até então disposições [Anlagen] significativas e singulares, expressando-as 
perfeitamente. Da mesma forma acontece com as nações cujos préstimos se expressam de forma total e de uma só vez, caso saia-se bem, em um indivíduo. Assim surge Luís XIV como um rei francês no mais alto sentido, e da mesma forma, Voltaire é o mais elevado tipo de escritor concebível entre os franceses e o mais de acordo com essa nação.

Ou um terceiro uso desse mesmo pensamento: "Foi a metamorfose de uma literatura secular que desde Luís XIV cresceu e, por fim, floresceu plenamente".

Natureza e história estão reunidas sob um mesmo olhar. Como crítico, Goethe é também historiador. Ele mostra as produções intelectuais a partir de suas bases históricas. Paris, "onde em cada canto se passou um pedaço da história", oferece condições para o desenvolvimento daquela brilhante literatura que se estende de Molière até Diderot. Os romances de Scott "repousam sobre o esplendor dos três reinos britânicos". Muito pelo contrário, o escritor alemão! A história dos primórdios da Alemanha se encontra em uma escuridão demasiadamente densa, a posterior não desperta em geral nenhum interesse nacional "devido à falta de uma única casa regente". Klopstock procurou se estabelecer com Hermann, "porém o objeto está muito distante, ninguém possui nenhuma relação com esse tema". E Lessing! Em sua Minna von Barnhelm teve de se contentar em tratar das contendas entre saxões e prussianos, porque não encontrou nada melhor. Ele nasceu em um tempo ruim e por isso necessitava de um efeito polêmico: em Emília Galotti deu sua "espetada" nos príncipes, em Nathan, nos padres. O próprio Goethe fez com Götz von Berlichingen uma feliz escolha. "Por outro lado, em Werther e no Fausto, tive de tocar em meu próprio peito, pois o que havia sido transmitido pela tradição não era grande coisa". Em Wilhelm Meister teve que escolher o assunto mais miserável que se possa conceber: "comediantes ambulantes e camponeses pobres". É um ancião que fala assim (1826). "Mas se soubesse, segue dizendo, de forma tão clara como agora, quantas coisas magníficas já existem há séculos e séculos, não teria escrito uma linha sequer, mas sim feito outra coisa".

\section{5}

Essas palavras podem parecer estranhas, mas elas esclarecem muita coisa. Bem na metade de sua vida, Goethe descobriu que ele teria "nascido para ser escritor". Porém, em 1791 ele declara a Jacobi que estaria, dia após dia, cada vez mais ligado às ciências naturais, e faz a seguinte declaração: "como consequência disso, provavelmente irei me ocupar exclusivamente delas". Por muito tempo acreditara estar destinado a tornar-se artista. Isso era, lançando mão de uma fórmula bastante significativa para ele, uma "falsa tendência". Uma história que demonstra isto é a que se desenrola em A missão teatral de Wilhelm Meister (Wilhelm Meister theatralische Sendung). Por muito tempo Goethe teve a "fantasia" de que seria possível instituir um teatro alemão e de que ele poderia contribuir para isso. "Eu escrevi a minha Ifigênia e o meu Tasso e tinha a esperança ingênua de que daria certo. Contudo, nada se mexeu nem se agitou e tudo permaneceu como era antes". Desenhista, pesquisador de ciências naturais, reformador do teatro, funcionário público, escritor - essas e outras possibilidades ele as tinha em si. Somente em idade avançada ele pôde lançar um olhar sobre elas. Nos últimos anos, ele se 
tornou, como único sobrevivente, histórico para si mesmo e até mesmo "mítico". Uma obra tardia como o Divã também se tornou, após uma década, estranha para ele: "é como uma pele de cobra que se desprendeu e ficou pelo caminho" (1827). Nos primeiros tempos em Weimar, Goethe já havia utilizado essa imagem para falar de si mesmo. A historização da própria vida, que induziu censores irracionais a criticar Poesia e verdade, não significa ossificação ou rigidez, mas sim um efeito da enteléquia. As etapas da vida que se completavam tornam-se transparentes e são suscetíveis de ser contempladas juntas, formando uma unidade mais elevada. Por isso, Goethe nomeou o poema "À meia-noite" (Um Mitternacht) - esse acorde perfeito - de sua "Canção da vida", "uma de minhas produções preferidas". Somente nessa fase mais elevada, Goethe acreditava saber "o quanto de excelente existe há séculos e milênios". O "excelente" como categoria de valor corresponde à fase da vida da idade mais avançada - pois implica a duração e, com isso, a noção de tempo que se conta por séculos e milênios. A juventude pensa em anos, a idade madura em quinquênios, em décadas:

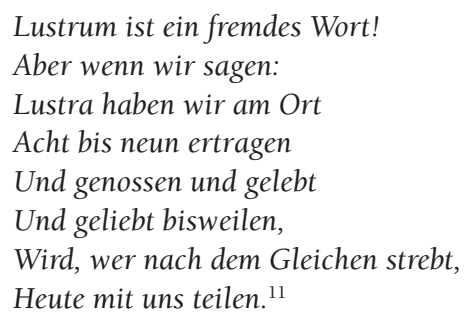

Em 1825 celebra-se o cinquentenário de Goethe como funcionário a serviço da corte. Em 1827, ele pensa se valeria a pena "ainda aguentar por mais outros cinquenta anos"; pois ainda gostaria de estar presente quando estivessem prontos o Canal do Panamá, o Canal de Suez e Canal do Reno-Danúbio. A construção de canais é uma das atividades de melhoria do solo empreendidas por Fausto. O palácio do último ato localiza-se em um amplo jardim, ornamentado junto a um "grande e retilíneo" canal, pelo qual chegam produtos das partes mais distantes da terra. Fausto é um centenário. O pensamento de todo um século está projetado no palco da existência humana. Desse modo se toca o campo da macrobiótica, que exercia uma atração tão mágica sobre os contemporâneos de Goethe. Ele gostava de falar, com aqueles que o visitavam em seus últimos anos de vida, sobre a longevidade de Ninos de Lenclos. Repreendia Sömmerring, que havia se deixado levar da vida aos 75 anos de idade. Ele pesava as "vantagens e desvantagens" das distintas fases da vida, concluindo que em seu octogésimo ano de vida possuía vantagens as quais não gostaria de trocar com as de antes. Após a morte de Karl

${ }^{11}$ [Lustrum é uma palavra estranha! / Mas quando dizemos: / Neste lugar temos suportado / oito ou nove lustros / E aproveitado e vivido / E amado algumas vezes / Aquele que almeja o mesmo / Compartilhará hoje conosco.] (Poema dedicado ao amigo von Knebel, escrito em 1817 e musicada por Zelter (N.T.)) 
August, lamenta-se de que não "há diferenças" e que semelhante homem tenha de ir tão cedo. "Apenas um mísero século a mais, e como ele teria feito seu tempo avançar a um estágio superior!"

À pretensão de uma vida de duração secular tem de corresponder uma consciência histórica milenar. Como diretor geral de obras públicas, Coudray conta que queria resguardar o túmulo de Wieland em Osmannstedt com uma cerca de ferro, ao que Goethe observa: "vivendo como vivo, em milênios, sempre me surpreendo pensando quando ouço falar de estátuas e monumentos. Não posso pensar no erguimento de uma estátua em homenagem a um homem de valor sem que a veja em ruínas, derrubada e destroçada por futuros guerreiros. Já vejo a cerca de ferro de Coudray em torno do túmulo de Wieland como ferraduras sob cascos de cavalos de uma futura cavalaria." Aquele que não sabe como dar conta de três milênios, permanece "no escuro, inexperiente".

Com o mesmo olhar de lince dirigido à carga vinda de países longínquos, Goethe contempla o régio tesouro de milênios. E com que modéstia! Ao contemplar pinturas de Pompeia, mergulha em devoção silenciosa e então irrompe a falar as seguintes palavras: "Sim, os Antigos são inalcançáveis em todos os campos da arte sagrada. Vejam, meus senhores, creio também ter feito algo, mas diante de um dos maiores poetas áticos como Ésquilo ou Sófocles, não sou absolutamente nada". Ou melhor: "em cinco séculos, os árabes reconheceram como bons apenas sete poetas e dentre aqueles que foram rechaçados havia muitos insignificantes que eram melhores do que eu". Ele considera Tieck como um talento de grande significância. "Mas é um erro querer elevá-lo acima de seus méritos e equipará-lo a mim. Posso dizer isso sem rodeios, pois no que se refere a mim, não fui além de mim mesmo. Seria como se quisesse me comparar a Shakespeare que também não foi além de si e que, contudo, é um ser da mais alta espécie, para quem eu levanto os olhos para olhar e a quem devo venerar". E finalmente: "Não tenho nenhuma ilusão em relação ao que fiz como poeta. Poetas excelentes viveram na minha época, outros ainda melhores viveram antes de mim, e viverão outros depois de mim". Essas e outras considerações semelhantes mostram-nos o quanto Goethe se classifica a partir de um ponto de vista milenar. Elas permitem interpretar a declaração de que ele não teria escrito coisa alguma, caso tivesse a clara consciência, "do quão extraordinário já foi feito há séculos e milênios". Elas apontam claramente para uma exigência que está colocada para todo crítico de um tipo mais elevado, mas que na realidade permanece não cumprida: a hierarquização dos autores. Isso significa também: distinção entre os espíritos.

\section{6}

A apropriação da poesia oriental ampliou o reino do Goethe crítico. Foi como uma campanha de Alexandre: Hélade e Ásia entraram em uma nova relação compreendendo frutíferas tensões. Nas Notas e ensaios sobre o Divã [Noten und Abhandlungen zum Divan], os europeus são chamados de "os ocidentais". Não era mais possível separar Oriente e Ocidente. Mas o Oriente não deveria ser ajustado ao Ocidente. Sir William Jones apreciava e amava seu Oriente. Somente a fim de 
"contrabandear" a produção oriental para seus conterrâneos, comparou-as com os gregos e latinos. Para isso necessitou do preconceito excludente dos "críticos clássicos" ingleses ("classicistas", como os chamava Goethe) que não admitiam como válido "nada além do que fora herdado por nós de Roma e Atenas". O descobrimento da poesia árabe e persa abriu uma brecha no classicismo de Goethe, mas ao mesmo tempo confirmou e reforçou um elemento cultural que Goethe havia recebido desde sua juventude, até mesmo desde sua infância: o elemento bíblico. O Antigo Testamento era para ele o protótipo da tradição, carregado de doutrina e poesia; continha os mais antigos documentos da humanidade. No período da juventude de Goethe podiam-se encontrar "na Alemanha protestante" leitores das Escrituras Sagradas que sabiam de cor todos os trechos mais importantes e que os tinham sempre prontos para uso e eram "uma concordância viva". Eram chamados de bibelfest, "fortes na Bíblia", e tal apelido "dava uma dignidade especial e uma recomendação inequívoca". Goethe se lembra deles quando no estudo da poesia oriental depara com os crentes que fortemente se atêm ao Corão e aos quais se concedia o título honorífico de Hafiz. Ao ser perguntado sobre o motivo pelo qual portava tal título, Mohamed Schemseddin respondeu:

Weil in glücklichem Gedächtnis
Des Korans geweiht Vermächtnis
Unverändert ich verwahre,
Und damit so fromm gebare,
Des gemeinen Tages Schlechtnis
Weder mich noch die berühret,
Die Propheten-Wort und Samen
Schätzen, wie es sich gebühret--
Darum gab man mir den Namen. ${ }^{12}$

Em concordância com ele, o poeta ocidental pode dizer:
Und so gleich ich dir vollkommen, Der ich unsrer heil'gen Bücher Herrlich Bild an mich genommen, Wie auf jenes Tuch der Tücher Sich des Herren Bildnis drückte, Mich in stiller Brust erquickte Trotz Verneinung, Hindrung, Raubens Mit dem heitern Bild des Glaubens. ${ }^{13}$

${ }^{12}$ Divã Oriental-ocidental, "Livro de Hafiz". [Pois em memória feliz / Sagrado legado do Corão / Sem alteração mantenho sob custódia / E ajo deste modo tão devotadamente / Que o Mal dos dias comuns / Nem a mim, nem àqueles atinge, / Quem as palavras e sementes dos profetas / Prezam, como dever ser - / Por isso me deram esse nome.] (N.T.)

${ }^{13} \mathrm{Idem}$, ibidem. [E assim inteiramente assemelho-me a ti, / Pois de nossos livros sagrados / Tomei para mim imagem magnífica, / Como naquele manto dos mantos / Se estampou a imagem do Senhor, / Meu peito tranquilo se revigorou, / Apesar de negações, obstáculos, roubos, / Com a serena imagem da fé.] (N.T.) 
Hafiz e Goethe encontram-se sob o signo das Sagradas Escrituras, e a imersão na poesia oriental coincide com um novo estudo da Bíblia. "Pois, assim como todas nossas peregrinações pelo Oriente foram sugeridas pelas Sagradas Escrituras, do mesmo modo retornamos sempre a elas, como a mais reconfortante água de nascente, e que, apesar de ser ocasionalmente turva e por vezes se esconder no solo, logo volta a brotar pura e fresca." A incursão de Goethe no mundo do Islã não era um exotismo, mas sim o retorno ao puro ar patriarcal do Oriente. Através dos diários de viagem de um Marco Polo, de um Pietro della Valle, de um Chardin, a visão de mundo foi ampliada até os últimos séculos e, no espaço, até a China, onde já havia romances excepcionais, "quando nossos antepassados ainda viviam nas florestas".

Nenhum conceito relativo à visão de mundo histórica de Goethe tornou-se tão conhecido como o de literatura mundial (Weltliteratur). Uma de suas raízes se encontra na assimilação do Oriente; em sua integração na tradição da humanidade. No ano 1831, Goethe diferencia em quatro outra teoria das fases da cultura: a idílica; a social ou cívica; a generalizada; a universal. Essa última "é a união de todos os círculos cultos que antes tinham alguns pontos de contato, o reconhecimento de um propósito, a convicção do quão necessário é se informar do presente estado das coisas do mundo. Todas as literaturas estrangeiras se assemelham à literatura nacional e não ficamos para trás no girar do mundo". O girar do mundo, a crescente "facilidade da comunicação", era um aspecto de sua época que Goethe saudava. Ele elogiava o serviço expresso dos correios, essa novidade dos meios de comunicação alemães, ${ }^{14}$ informou-se com interesse sobre a inauguração da navegação a vapor pelo Reno e sobre a máquina voadora de Degenhardt. Os canais dos Parsis, "de cuja circulação surgiu a fertilidade do país", prenunciam a construção de canais no Fausto. Ele tinha esperanças de uma unificação da Alemanha, isto é, da entrada da Prússia na aliança aduaneira do sul da Alemanha, do mesmo sistema monetário, de medidas e peso - mas que se observe bem, sem nenhuma unificação estatal: "pressuposto que tivéssemos há séculos na Alemanha apenas as duas capitais Berlim e Viena, ou apenas uma, então gostaria de ver como estaria a situação da cultura alemã". Ele esperava que a unificação da Alemanha viesse por meio "de nossas estradas e futuras linhas férreas". Tudo isso ressoa no conceito de literatura mundial. A dois visitantes poloneses, a quem serve "um maravilhoso peru com trufas", ele explica que, para a multidão cega, as diferenças nacionais tomam a forma de barreiras intransponíveis. Disso resulta então a obrigação dos mais bem formados de influir de modo atenuante nas relações entre os povos, da mesma maneira pela qual devem facilitar as navegações ou abrir caminhos nas montanhas. O livre comércio de conceitos e formas de sentir intensifica a riqueza e o bem-estar geral da humanidade, da mesma maneira como o trânsito em forma

\footnotetext{
${ }^{14}$ Trata-se aqui do conceito de "Schnellposten", correio expresso, introduzido em janeiro de 1819 (Berlim-Magdeburg) no serviço dos correios da Prússia. Era um serviço que garantia uma entrega, consequentemente, uma viagem mais rápida. Isso influenciou na melhoria das estradas e na extensão de redes de transportes. (N.T.)
} 
de produtos e frutos do solo. A palavra literatura mundial (Weltliteratur) não surge na conversa, mas seu conceito é desenvolvido e, na verdade, como complemento de um ideal de livre comércio. Segundo o ponto de vista de Goethe, assim como a liberdade aduaneira não deveria produzir uma unificação política da Alemanha, do mesmo modo ele não coloca a literatura mundial (Weltliteratur) em oposição às literaturas nacionais. Por vezes, acentua mais fortemente o universal, por outras, mais o "nacional". Como todos os conceitos de Goethe, o de literatura mundial não possui uma restrição de definição, mas sim um ponto de unidade de muitas relações, centro de perspectivas divergentes: ele é uma incumbência. À época do Divã, ele recebeu uma reprimenda por conta do preconceito classicista. Porém, depois de passada essa época, o pêndulo retorna para a Antiguidade:

literatura nacional não quer dizer mais nada, estamos na época da literatura mundial e agora todos devem atuar para que essa época se acelere. Contudo, também não podemos em tal valoração do estrangeiro ficar presos a algo especial e o tomarmos como exemplo a ser seguido. Não devemos pensar que o chinês seria esse modelo, ou o sérvio, ou Calderon, ou os Nibelungos; devemos sim, quando tivermos a necessidade de algo exemplar, voltar aos gregos, em cujas obras o belo homem sempre é representado. Devemos vislumbrar todo o restante apenas historicamente e o bom, na medida do possível, de lá nos apropriarmos.

Na medida do possível! O modo de pensar imbricado de Goethe está em oposição ao sistemático: quando ele estabelece uma posição, está também inclusa a negação. "Alemanha", diz após a visita do jovem poeta, "está em todas as matérias em uma posição tão elevada que quase não é possível alcançar com a vista e, além disso, ainda devemos ser gregos, latinos, e ingleses e franceses. A isso se soma a maluquice de também indicar para o Oriente e aí um jovem tem de ficar completamente confuso."

Tem-se a maluquice... por acaso Goethe também não faz parte disso? Porém, apenas seis anos mais tarde:

Imagina-se em vão que se poderia fazer face a todas as manifestações literárias; mas é inútil; tateia-se por todos os séculos, por todos as partes do mundo e em nenhum lugar sentimo-nos em casa; embotam-se os sentidos e o juízo, perde-se tempo e forças. Isso acontece comigo mesmo; me arrependo, mas tarde demais. Alguns passam a vida folheando in-fólios e in-quartos e não se tornam nem um pouquinho mais inteligentes do que se tivessem lido a Bíblia todos os dias; a única coisa que se aprende é que o mundo é estúpido e isso se pode comprovar em qualquer ruela por aqui.

In-fólios e in-quartos: podemos conferir através da utilização da biblioteca de Weimar por Goethe, toda anotada nos registros. Como resultado dessa investigação, constata-se que Goethe lia diariamente em média pelo menos um volume médio in-oitavo. A lista de obras tomadas de empréstimo revela a amplitude de seus interesses. Goethe possui um pouco daquele poli-historicismo literário que também encontraremos em Herder e em Jean-Paul. Aqui também encontramos uma das raízes da concepção goethiana de literatura mundial. Mas a poli-história se coloca a serviço de um tipo superior de modo de reflexão: a comparativa. Ela 
incorpora tanto sua ciência natural e como sua teoria da história. Quando aplicada à literatura, ela produz a ideia de uma história da literatura comparada, o que, por sua vez, novamente contribui para a crítica: quando começa a elogiar o maneirismo de Jean-Paul, traço que, em seu período clássico, ele havia rejeitado completamente, Goethe o faz através de semelhanças com a poesia oriental. Graças ao método comparativo, a poli-história se eleva a uma consideração genuinamente histórica. A partir daí se desenvolve uma relação mais ampla. Como pesquisador da natureza, assim como historiador, Goethe informa sobre a história da pesquisa. As Notas e escritos sobre o Divã e a História da teoria das cores propiciam história da ciência e dos sábios, misturadas com considerações pessoais. Com isso é dado à história da literatura uma área na qual ela, na verdade, raramente entra de modo suficiente. Frequentemente entre nós, ela se limita em demasia à história da Poesia [Dichtungsgeschicht], permanecendo no ar a pergunta sobre a forma pela qual se poderia separar sensatamente Poesia (Dichtung) de Literatura (Literatur).

Qual é a essência da Poesia? Qual é o seu lugar no sistema do "espírito objetivo"? Sua função na sociedade humana? Sua relação com as artes plásticas e da oratória? Com a filosofia? Essas são questões que, desde Homero, são sempre feitas e respondidas de formas diferentes. Tomadas em conjunto, podem se caracterizar como teoria poética (Dichtungstheorie). Esse complexo carece de minuciosa investigação histórica. Isso faria bem tanto à história da literatura como à crítica. Mas também ao entendimento de Goethe - que de modo algum está concluso essa forma de abordagem poderia oferecer uma contribuição fundamental. Isso é obstruído por interpretações convencionais. Quando se discute sobre sua teoria poética, então se costuma remeter para o fato de que ele qualificou suas obras como partes de uma grande confissão (Konfission), mas também como poesias de ocasião (Gelegenheitsdichtung). Mas o que propriamente se quer dizer com isso?

Entende-se poesia de ocasião da seguinte forma: na Antiguidade tardia, a oratória tinha lugar quase que apenas em festividades privadas ou públicas, nos chamados discursos de ocasião (Gelegenheitsreden). ${ }^{15}$ Havia uma grande demanda de panegíricos, de discursos de saudação, discursos em festas, de convite, de saudação, de despedida, de casamento, de nascimento, de consolo e de outros tipos semelhantes. Na Idade Média, na Renascença e nos tempos seguintes, todos esses tipos são transpostos para a poesia, considerada como parte da Retórica. Ao discurso casual correspondia a poesia casual. Encomendavam-se poesias de ocasião para festividades. Na época da juventude de Goethe elas circulavam amplamente. O rapaz contemplava-as com certa inveja, porque ele "acreditava poder fazer tais coisas tão bem ou, talvez, ainda melhor". Logo se deu a oportunidade para isso, por meio do primeiro suave idílio amoroso que é tecido em torno da Gretchen de Offenbach. ${ }^{16}$ Goethe relata o relacionamento graciosamente em Poesia e verdade. Compõe epitalâmios e outras carmina. São poesias de ocasião em sentido próprio

\footnotetext{
${ }^{15}$ Ver o capítulo "Retórica" do meu livro Literatura europeia e Idade Média latina (Bern 1954). [Nota do autor.]

${ }^{16}$ Cidade alemã às margens do rio Meno. (N.T.)
} 
e original. Porém, a criação lírica livre obedece a leis bem distintas. "Eu cheguei à conclusão", observa Goethe a respeito de seus Estudos de Espinosa em Frankfurt, ${ }^{17}$ "que o talento poético que em mim residia devia ser visto como algo natural, ainda mais quando me dispunha a considerar a natureza exterior como objeto dele. $\mathrm{O}$ exercício desse dom poético podia ser incitado e determinado por algum motivo; mas quando surgia involuntariamente, contra a vontade, era o mais feliz e rico possível." Esse exercício poético espontâneo e natural é caracterizado aqui como oposto à elaboração de poemas festivos. Mas já em Poesia e verdade o uso linguístico se desloca. Na homenagem a Johann Christian Günther, a poesia de ocasião é chamada de "a primeira e mais genuína de todas as formas de poesia". Nos anos 1920, a palavra tinha o mesmo significado de poesia objetiva. Goethe declarava a respeito de seus trabalhos que eles seriam todos "estimulados por uma ocasião de maior ou menor importância, compostos na contemplação imediata de um objeto qualquer". De forma ainda mais clara diz a Eckermann: "O mundo é tão grande e rico e a vida tão múltipla que nunca faltarão motivos para poesias. Mas todas elas precisam ser poesias de ocasião, quer dizer, a realidade tem de propiciar o ensejo e o tema para isso... Eu não dou o menor valor a poesias tiradas do ar". A subjetividade é "a doença geral dos tempos de hoje". Na medida em que um poeta "expressa apenas suas poucas sensações subjetivas, não deve ser chamado como tal; mas tão logo ele se apropria do mundo e sabe expressá-lo, ele é um poeta". Poesia de ocasião é então o oposto da expressão de estados pessoais. Ela é poesia plena de conteúdo do mundo.

Essa explicação me pareceu necessária, porque a palavra do poeta de ocasião Goethe se tornou uma convenção sem pensamentos que a sustentem. Assim também com a fórmula pobre "vivência e poesia" [Erlebnis und Dichtung] se ganha pouco. Goethe estabeleceu para sua poesia cunhos bem diferentes. Caso os coloquemos à prova, elas se ordenam em uma sequência gradativa. Tentaremos explicá-la.

No primeiro degrau, a poesia aparece como fenomenologia da vida humana. Ela condensa e dá forma às errâncias do coração, às complicações da vida em comum. Ao mesmo tempo, isso significa um caminho para o conhecimento, para a sabedoria, para a saúde. O poeta, diz Wilhelm Meister,

vê movimentarem-se sem propósito o emaranhado das paixões, famílias e reinos, vê os insolúveis enigmas dos enganos, aos quais frequentemente falta apenas uma palavra monossilábica para que sejam resolvidos, eles provocam confusões indizivelmente arruinadoras... Nascidas no solo do coração, cresce a bela flor da sabedoria e, enquanto os outros sonham despertos e temem diante de suas representações monstruosas vindas de todos seus sentidos, ele vive então o sonho da vida como um ser em vigília, e acontece o fato mais extraordinário, para ele o passado é ao mesmo tempo futuro. Dessa forma, o poeta é ao mesmo tempo professor, vidente, amigo dos deuses e dos homens.

O pretenso egoísta Goethe (conforme Schiller o considerava nos anos 1788/1789) pode, como amigo dos homens, proferir as comoventes palavras:

${ }^{17}$ Poesia e verdade. (N.T.) 
Warum sucht ich den Weg so sehnsuchtsvoll, Wenn ich ihn nicht den Brüdern zeigen soll? ${ }^{18}$

Ele procura o caminho, vê sua vida como "decurso labirinticamente errante", mas ao mesmo tempo como uma pirâmide que foi posta diante de si. Ele a trilha degrau por degrau em direção ao alto.
Weltverwirrung zu betrachten,
Herzensirrung zu beachten,
Dazu war der Freund berufen,
Schaute von den vielen Stufen
Unsres Pyramidenlebens
Viel umher und nicht vergebens:
Denn von außen und von innen
Ist gar manches zu gewinnen. ${ }^{19}$

O último desdobramento desse diagnóstico fenomenológico nos fornece a estrofe:

Des Menschen Leben scheit ein herrlich $\operatorname{Los}^{20}$

Com os versos-chave:

Keins wird vom andern wünschenswert ergänzt,

Von außen düstert's, wenn es innen glänzt, ${ }^{21}$

A despeito disso, a "Reconciliação" é transposta para a música.

Poesia como exposição e esclarecimento de uma "aspiração confusa", inserida em uma fenomenologia da existência humana - isso é uma constante na poesia [Dichtung] goethiana. No esquematismo tradicional da teoria poética essa concepção não tem lugar. Porém, ela é uma chave para âmbitos mais amplos da criação poética goethiana. Ela pode desdobrar-se em poesia [Gedicht], em drama, em mascarada, em romance. Ela perpassa todos os gêneros e os conecta como algo orgânico que se deixa reconhecer nas mais variadas formas. Antes de Goethe ela não existia no mundo, nem voltou a existir depois dele. Ela é a contribuição de Goethe para a teoria da criação literária, unida à sua mônada.

Mas em seu caminho, o Goethe pesquisador de história e teórico da literatura também teve que se encontrar com teorias poéticas mais antigas. Uma tradição erudita, que foi herdada dos tempos da Antiguidade tanto pelo Islã como pelo

18 [Por que procurei o caminho tão ansiosamente, / Se não devo mostrá-lo aos irmãos?] (N.T.)

${ }^{19}$ [Contemplar a balbúrdia do mundo / Observar a errância do coração / Para isso o amigo foi predestinado / Dos mais altos patamares / Da nossa pirâmide da vida / Olhava bastante em torno, / E não era em vão: / Pois interior e exteriormente / Há muito o que se ganhar.] (N.T.)

20 [A vida humana parece um fado esplêndido.] (N.T.)

${ }^{21}$ [Nunca uma coisa é completada por outra satisfatoriamente; / Por fora está escuro, quando reluz no interior.] (N.T.) 
Ocidente e que continuou através da Idade Média e Renascimento até o século XVIII, uniu Poesia e retórica como "belas artes da palavra". Em sua jornada pela literatura mundial, Goethe censurou essa "categoria geral". Ela avilta a Poesia na medida em que a coloca ao lado da Retórica, quando não subordinada a ela. Essa "Custódia" [Verwahrung] de Goethe deveria ser apreciada como detentora de significado histórico. Ela se mostrou a ele durante a pesquisa sobre a poesia oriental, quando se colocou diante dele uma forma poética de cunho mais puro e da qual ele se apropriou com o sentido profundo dado por uma idade capaz de abarcar milênios com a vista: o gênero encomiástico, como ele o chama, valendo-se de um termo técnico da retórica grega. Enkomion significa louvor, elogio. Poesia encomiástica é, ante de tudo, elogio aos príncipes. Encontramo-la também nas cortes helênicas e ocidentais, mas não tão ricamente desenvolvida como no Oriente. O persa Enweri é "um encomiasta livre e acha que nenhum ofício é melhor do que entreter com elogios as pessoas. Príncipes, vizires, mulheres nobres e belas, poetas e músicos - ele adorna com seus discursos laudatórios e a cada um sabe atribuir algo ornamental, colhido do extenso estoque do mundo". Elogiar é a função própria do poeta da corte. Mas o conceito de elogio se converte também em uma cifra que Goethe tem como a quintessência de toda a poesia. Ainda mais! No velho Goethe, a palavra "elogiar" (louvar) está repleta de um conteúdo solene uma abreviatura de uma visão de mundo transfigurada (metamorfoseada). Desprendido do círculo da palavra é transferido para a esfera do ser.

Em noite estrelada, Goethe olha o infinito

Wenn sie sich einander loben,

Jene Feuer in dem Blauen ${ }^{22}$

A história se transforma em Te Deum: o panegírico da humanidade que a Divindade escuta com tanto gosto nunca emudeceu e nós mesmos sentimos uma ventura divina quando ouvimos uma emanação harmônica dispersa por todos os tempos e lugares, ora em vozes singulares ou em coros, ora em fugas, ora em forma de vozes que entoam um só canto [Vollgesang]. Um canto de louvor que se eleva através de todas as esferas até o Empíreo - isso se revela então como a essência da Poesia.

Nesta ocasião há muito a se observar: que o verdadeiro poeta é chamado a captar em si a magnificência do mundo e, por isso, se sempre sentirá mais inclinado a louvar do que a censurar. A isso segue o fato de que procura encontrar o objeto mais digno de todos e, depois de ter passado por tudo, emprega seu talento de preferência para louvar e glorificar a Deus.

Poesia como elogio e louvação a Deus - Carmen Deo nostro - seria, portanto, outro aspecto da teoria da poesia de Goethe. No entanto, louvor a Deus feito por um crente que não era um crente propriamente dito. Mas eram ortodoxos os venerados poetas persas? Havia lugar nas leis religiosas do Islã para a Poesia? Até mesmo o fundador dessa religião teve de protestar contra o fato de o terem colo-

22 [Ao se louvarem uns aos outros, / Aqueles fogos no azul.] (N.T.) 
cado no mesmo patamar dos poetas do tempo pagão. Mas no desenvolvimento ulterior, ao lado da lei e da dogmática, surgiu uma mística que poderia ser vista como em oposição à prática ortodoxa, sobretudo quando ela se servia de uma simbologia erótica. Entre os grandes da poesia persa estavam homens como Hafiz, a cujas poesias podiam ser atribuídas significado religioso e mundano. O Oriente parecia possuir também a possibilidade de uma piedade poética mundana e supramundana que permanecia negada ao Ocidente e, com isso, a possibilidade de uma nova "magnificência da Poesia". Uma magnificência "na qual se refugiam pura humanidade, nobres costumes, júbilo e amor, para nos consolar das lutas de castas, de fantásticas monstruosidades da religião e do misticismo abstruso e para nos convencer de que, por fim, nela permaneceria conservada a salvação da humanidade". Em sua "magnificência" a Poesia abriga a salvação da humanidade. A salvação, porém, é um conceito da esfera religiosa. Portanto, também dela se aproxima a concepção de Poesia que se contrapõe de modo consciente à degeneração da fé. Contudo, a religião do profeta concede ao poeta seu direito. Os dois tipos de pessoas espiritualizadas estavam abrigados naquela esfera religiosa; mesmo que em uma separação complementar.

Caso então queiramos explicitar mais especificamente a diferença entre poeta e profeta, digamos o seguinte: ambos são possuídos e inflamados por um Deus, porém o poeta desperdiça o talento que lhe foi dado no prazer, para produzir novos prazeres e alcançar honrarias pelo que produziu e quando muito uma vida confortável. Ele negligencia todos os outros propósitos, procura ser polivalente, mostrar-se ilimitado em relação a convicções e representações. O profeta, ao contrário, vê um único propósito, e para alcançá-lo serve-se dos meios mais simples.

Neste ponto, abrem-se duas perspectivas. Poesia como fruto e meio do prazer. Nossos pedagogos não se cansam de repetir - ter prazer nos faz vulgar. Mas em relação a esse assunto, Goethe tem algo bem diferente a dizer. Ele fornece uma ética do prazer, do próprio e - uma etapa mais elevada da vida - do substitutivo.

\footnotetext{
Was ihr sonst für euch genossen.

Läßt in andern sich genießsen.

Niemand wird uns dann beschreien,

Daß wir's uns alleine gönnen;

Nun in allen Lebensreihen

Müsset ihr genießen können.

Und mit diesem Lied und Wendung

Sind wir wieder bei Hafisen,

Denn es ziemt, des Tags Vollendung

Mit Genießern zu genießen. ${ }^{23}$
}

${ }^{23}$ [O que outrora havíeis gozado outrora / Deixai que outros dele se deliciem / Ninguém irá então nos reclamar / Que quisemos somente nosso regalo; / De ora avante em todas as aparas da vida / Deveis poder se deleitar / E com essa canção e giro / nos encontramos novamente junto a Hafis; / Pois convém para que o dia seja completo / Deliciar-se com quem sabe se deleitar.] (N.T.) 
A poesia de deleite de Anacreonte, a de Hafiz, a de Goethe: patamares da pirâmide da vida da literatura mundial.

Como aquele deleitante e criador de deleites, o poeta é um pródigo. Esse pensamento nos conduz do Divã ao Fausto. Na cena da mascarada no paço imperial, o arauto anuncia vários poetas: "poetas da natureza, poetas da corte e de cavalaria, uns ternos, outros entusiastas". Na aglomeração de concorrentes de todo tipo, nenhum deixa o outro tomar a palavra. O satirista, ao passar furtivamente, diz algumas palavras. Os poetas da noite e dos sepulcros se desculpam, "porque se acham em conversação com um vampiro recém surgido, do que talvez possa resultar um novo tipo de poesia". Deles se prescinde e evocando-se a mitologia grega, "a qual, mesmo sob uma fantasia (máscara) moderna, nada perdeu de seu caráter, nem de seus encantos". No desfile de máscaras surge um carro, dirigido por um belo rapaz. Quando perguntado pelo arauto, ele se define:

Bin die Verschwendung, bin die Poesie;

Bin der Poet, der sich vollendet,

Wenn er sein eigenst Gut verschwendet. ${ }^{24}$

Se, em Platão, Eros é o filho da Pobreza e da riqueza, ao Rapaz-guia é dado como pai Plutus, o deus da riqueza, "um rei rico e benevolente". Plutus traz riquezas para a corte imperial. Ao esvaziar as arcas com os tesouros, ele se volta para o Rapaz-guia e diz:
Nun bist du los der allzu lästigen Schwere,
Bist frei und frank, nun frisch zu deiner Sphäre!
Hier ist sie nicht! Verworren, scheckig, wild
Umdrängt uns hier ein fratzenhaft Gebild.
Nur wo du klar ins holde Klare schaust,
Dir angehörst und dir allein vertraust,
Dorthin, wo Schönes, Gutes nur gefällt,
Zur Einsamkeit! - Da schaffe deine Welt. ${ }^{25}$

Junto ao Rapaz-guia coloca-se eufórion. As duas figuras são representações do protótipo [Urbild]: ${ }^{26}$ é a Poesia em sua "magnificência", aparecendo e desvanecendo como um gênio juvenil. Ambos são jovens, ambos vivem protegidos, sob os cuidados de um pai bondoso que logo os põe em liberdade. Seria errôneo interpretar a figura do pai com uma simbologia psicológica demasiadamente categórica.

${ }^{24}$ [Sou a abundância, sou a Poesia / Sou o Poeta que se completa / Ao dissipar sua própria fortuna.] (N.T.)

${ }^{25}$ [Da mui pesada carga estás liberto, / És enfim livre, à tua esfera corre! / Aqui ela não é. Confusas, rudes / Aqui nos cercam formas monstruosas / Só onde a mente é clara, e a serena claridade olhas / a ti pertences e em ti só confias; / Lá ode o Belo e Bom melhor nos prazem, / Na solidão: - aî teu mundo forma!] (N.T.)

${ }^{26}$ Usou-se a palavra "protótipo" na acepção etimológica de "o primeiro tipo, de criação primitiva, primitivo". Cf. Dicionário Houaiss. (N.T.) 
Entretanto, uma coisa é certa: o gênio encarnado como rapaz - última encarnação da ideia da Poesia de Goethe - deve ser visto em conjunto com a imagem de uma potência criadora, cuja esfera abarca a do filho. A esfera da Poesia é uma região demarcada e purificada do ser do mundo [Weltwesen]: "Só onde a mente é clara, e a serena claridade" - esse único verso expressa com a mais vigorosa concisão a essência da teoria goethiana da poesia e da vida: uma visão clara dirigida à claridade; um interior claro que dialoga com o claro exterior. Luz do dia "tecida de vapores da aurora e da claridade solar"; luz das eternas estrelas quando se tornam claros a noite e o éter: dupla forma de aparição do mundo "sereno", ao qual Goethe, ansioso por luz, se sabe ligado. A Idade Média conheceu uma metafísica da luz. Encontramos em Goethe uma poética da luz que abrange o divino e o humano, o Oriente e o Ocidente, o passado e o presente.

La $\beta$ den Anfang mit dem ende sich ins eins zusammenziehen ${ }^{27}$

Esse verso exprime o que há de mais peculiar no sentimento goethiano da vida e remete os leitores de Goethe a outras passagens que expressam o mesmo. Citemos apenas uma, por ela possibilitar um olhar final sobre o domínio da metamorfose na poética goethiana:

certos grandes motivos, legendas, antiquíssimas tradições históricas gravaram-se tão profundamente na alma que eu as mantive vivas e atuantes em meu íntimo por quarenta ou cinquenta anos; me parecia ser meu bem mais precioso, ver essas valiosas imagens frequentemente renovadas em minha imaginação já que, na verdade, elas se metamorfoseiam repetidamente sem contudo perderem sua essência, amadurecendo até uma forma mais pura, até uma representação mais definitiva.

Por meio século Goethe traz em si imagens que chegaram até ele pela tradição e que o deixaram para se converterem em criações artísticas. A declaração é significativa. Elas aludem à relação entre consciente e inconsciente na criação de Goethe, e os "grandes motivos, legendas, antiquíssimas tradições históricas" podem ser entendidos como uma alusão quase imperceptível às imagens arquetípicas no sentido de C. G. Jung. Elas emergem uma vez ou outra da corrente na qual legenda e história estão misturadas. Ele une sua criação à cadeia áurea das tradições da humanidade. Aquelas imagens são a carga do suprapessoal e supra-histórico. Ocupam a posição mais elevada no mundo hierarquizado que Goethe chama de objetivo. É um conceito que em diversos graus de seu teor também predomina de modo peculiar em sua crítica de valor. Não devemos nos estender aqui sobre suas normas e conceitos fundamentais. Já é suficiente para nós termos esclarecido nossa compreensão de Goethe em alguns pontos.

Tradução de Magali Moura do texto original em alemão "Goethe as Kritiker".

27 [Deixai que início e fim em um só se reúnam.] (N.T.) 